(C) 1980. The Genetical Society of Great Britain

\title{
EVIDENCE FOR INDEPENDENT MISMATCH CORRECTIONS ALONG THE SAME HYBRID DNA TRACT DURING MEIOTIC RECOMBINATION IN ASCOBOLUS
}

\author{
A. KALOGEROPOULOS and J.-L. ROSSIGNOL \\ Laboratoire de Génétique, Centre \\ d'Orsay Université Paris XI (Paris-Sud) 91405 Orsay-Cedex, France
}

Received 14.ii.80

\section{SUMMARY}

\begin{abstract}
A three-point cross in the $b 2$ locus of Ascobolus immersus was devised in such a way that asci showing independent correction tracts within the same length of heteroduplex could be selected. The occurrence of independent corrections was confirmed. The calculation is compatible with the idea that the distances between the markers used was often, and perhaps always, in excess of the length of the correction tracts.
\end{abstract}

\section{INTRODUCTION}

IN Ascomycetes, ascus analysis from mutant $\times$ wild-type crosses shows departures from mendelian 4:4 segregations. In eight spored-asci, these aberrant segregations are $6: 2(6+2 \mathrm{~m}$ and $2+6 \mathrm{~m})$ and post-meiotic segregations (PMS). In $5: 3(5+3 \mathrm{~m}$ and $3+5 \mathrm{~m})$ the PMS involves one meiotic product; in aberrant $4: 4$, it involves two meiotic products. All these aberrant segregations can be explained by hybrid DNA (HDNA) formation followed by a facultative correction of the mismatch arising at the site of heterozygosity. HDNA can involve only one chromatid (asymmetrical HDNA). In this case $6: 2$ segregations result from mismatch correction and $5: 3$ segregations result from non-correction. HDNA can also involve the two interacting chromatids (symmetrical HDNA), so that two mismatches are formed: $6: 2$ segregations result from the correction of both mismatches, $5: 3$ segregations result from the correction of only one mismatch and aberrant $4: 4$ segregations result from non-correction on both mismatches.

The existence of mismatch correction in bacterial cells was demonstrated with artificial heteroduplex molecules (Spatz and Trautner, 1970; Wildenburg and Meselson, 1975; Wagner and Meselson, 1976). Evidence for mismatch correction during meiosis in Ascomycetes comes from the demonstration that $6: 2$ segregation at one site can decrease $5: 3$ segregation and increase $6: 2$ segregation at a closely linked site (Leblon and Rossignol, 1973; Rossignol and Haedens, 1978; Fogel et al., 1979). This change in the conversion pattern at the closely linked site also indicates that the correction process involves a length of the HDNA segment. However, 6:2 segregations at one site associated with a 5:3 segregation at another site are also observed, indicating that the repair tract does not always cover the whole HDNA segment.

The question now arises whether two mismatches formed in the same hybrid DNA segment can undergo independent repair. If so, it is expected that the two repair tracts can leave a third mismatch, located in between, 
unrepaired. At present there is only indirect evidence of the occurrence of independent corrections. Fincham and Holliday (1970) showed that, if the lengths of correction tracts were distributed about a mean length, a mixture of recombination resulting from heteroduplex ending and from independent correction could be the cause of map expansion which was observed in several genes. Independent correction has been postulated also to explain the occurrence of an associated crossover separated from a conversion by an unconverted length as the origin of the rare crossover class (Whitehouse and Hastings, 1965). This paper reports direct evidence of the existence of independent correction tracts based on the analysis of a 3-point intragenic cross in Ascobolus.

\section{MATERIAL AND METHODS}

\section{(i) Culture media and crossing conditions}

These have been described previously (Rizet et al., 1960; Lissouba et al., 1962; Yu-Sun, 1964). Crosses were performed at $22^{\circ} \mathrm{C}$. Asci were harvested at $11^{\circ} \mathrm{C}$ (Rossignol and Haedens, 1978).

\section{(ii) Mutant sites}

The strains used belong to stock 28 of Ascobolus immersus (Rizet et al., 1969). All the spore colour mutants used belong to the $b 2$ locus (Leblon, 1972a). F6 and A1 are EMS induced frameshift mutants. They give no PMS and an excess of $6+2 \mathrm{~m}$ over $2+6 \mathrm{~m}$ segregation (type A; Leblon, $1972 b$ ). F 6 and A 1 belong to the $F$ and $A$ groups of intragenic suppression respectively (Leblon and Paquette, 1978). The $F$ group lies toward the high conversion end of the $b 2$ locus and the $A$ group lies toward the low end. G1 gives numerous PMS besides $6: 2$ segregations (type $C$ ). It is a spontaneous mutant of unknown chemical nature. G1 is located within the $E$ group which lies in the middle of the locus (Rossignol, Paquette and Nicolas, 1979). The conversion patterns of the 3 mutants used are given in table 1 .

\section{TABLE 1}

Conversion patterns of the three b2 mutants used (Sources: Leblon, 1972b; Paquette and Rossignol, 1978; Paquette, 1979). All values are given in percent of the total number of asci. BFC: Basic frequency of conversion; Other: $8+0 m, 0+8 m, 7+1 m$, $1+7 m$ segregations.

$\begin{array}{lcccccc}\text { Mutant } & \text { BFC } & 6+2 \mathrm{~m} & 2+6 \mathrm{~m} & 5+3 \mathrm{~m}+3+5 \mathrm{~m} & 4: 4 & \text { Other } \\ \text { b2.F6 } & 22 & 16 & 5 & <1 & 0 & 1 \\ \text { b2.G1* } & 18-20 & 0 \cdot 4-1 & 1-2 & 13-15 & 2-3 & 0-0 \cdot 3 \\ \text { b2.A1 } & 17 & 13 & 1 & <1 & 0 & 2\end{array}$

* The extreme values observed in different crosses are given.

\section{(iii) Cross and ascus selection}

In a cross $\mathrm{X}+\mathrm{Z} \times+\mathrm{Y}+$, where $\mathrm{X}, \mathrm{Y}$ and $\mathrm{Z}$ are three allelic mutant sites, independent correction can be detected when HDNA spans the 3 sites in the $X+Z$ chromatid and when two independent corrections to wild-type involve $\mathrm{X}$ and $\mathrm{Z}$ and do not include the middle site $\mathrm{Y}$ (fig. 1). Indeed, this will lead to a detectable $1 \mathrm{C}: 7 \mathrm{~W}$ (1 coloured: 7 white spored-ascus) with a $6+2 \mathrm{~m}$ 


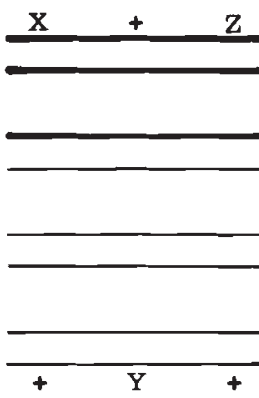

A

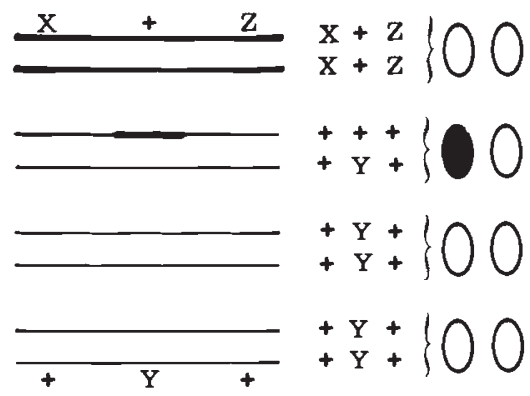

B

FIG. 1.- - HDNA segment involving $X, Y$ and $Z$ mutant sites is formed in the $X+Z$ chromatid (A). Correction to wild-type of $\mathrm{X}$ and $\mathrm{Z}$ mismatches and no correction of the $\mathrm{Y}$ mismatch (B) leads to a $1 \mathrm{C}: 7 \mathrm{~W}$ ascus.

segregation at $\mathrm{X}$ and $\mathrm{Z}$ and a $3+5 \mathrm{~m}$ segregation at $\mathrm{Y}$. The cross analysed was $r n d 1^{+}$vag $4^{+} b 2-\mathrm{F} 6 \mathrm{~A} 1 \times$ rnd $1-2$ vag4-1b2-G1. F6 and $\mathrm{A} 1$ mismatches are always corrected, with a preferential correction to wild-type, whereas G1 mismatches are rarely corrected. Of the two other markers used in this cross, rnd 1 gives round instead of oval spores and vag 4 gives a wavy mycelial growth; $b 2$, rnd 1 and vag 4 are unlinked (Nicolas, 1978). rnd 1 and vag 4 were used to distinguish between the 4 pairs of sister spores corresponding to each meiotic product.

\section{(iv) Analysis of $1 C: 7 \mathrm{~W}$ asci}

Several types of segregation for the three $b 2$ markers may lead to asci with one wild-type spore (tables 3 and 4). In order to distinguish between these segregations, a sample of $1 \mathrm{C}: 7 \mathrm{~W}$ asci was analysed. This analysis was achieved in 2 steps. One $b 2$ strain from each meiotic product was first crossed with the double mutant $b 2-\mathrm{F} 6 \mathrm{~A} 1$. The absence of wild-type spores in the progeny indicates that the $b 2$ strain is mutant for at least F6 or A1. The presence of wild-type spores indicates that the $b 2$ strain is $+\mathrm{G} 1+$. The cross with $b 2-\mathrm{F} 6 \mathrm{~A} 1$ defined 3 distinct classes of $1 \mathrm{C}: 7 \mathrm{~W}$ asci (Table 3 ). The classes I and II cannot correspond to a $6+2 \mathrm{~m}$ segregation for both F6 and A1. They were then disregarded in further analysis. In a second step, all 7 strains issued from the white spores of class III asci were crossed to the 3 tester strains: $b 2-\mathrm{F} 6, b 2-\mathrm{G} 1$ and $b 2-\mathrm{A} 1$. The full $b 2$ genotype was thus established.

\section{Results}

The numbers of the various phenotypic classes of ascus observed in a sample of the progeny of the cross $m d 1^{+}$vag $4^{+}$b2-F6A1 $\times$md 1-2 vag 4-1 $b 2-\mathrm{G} 1$ are given in table 2 . The frequency of $1 \mathrm{C}: 7 \mathrm{~W}$ asci is 0.065 . A sample of $1111 \mathrm{C}: 7 \mathrm{~W}$ asci was analysed (table 3 ). In the first step of the analysis, asci are classified in 3 classes. Class III ( 27 asci) is compatible with a $3+5 \mathrm{~m}$ segregation for $\mathrm{G} 1$ and a $6+2 \mathrm{~m}$ segregation for both F6 and A1. This is exactly the type of segregation expected if there is independent 


\section{TABLE 2}

Types and number of asci in the progeny of the cross $\mathrm{nnd}^{+} \mathrm{vag} 4^{+} \mathrm{b} 2-\mathrm{F} 6 \mathrm{A1} \mathrm{mt}^{-} \times$ rnd $1-2$ vag $4-1 \mathrm{~b} 2-\mathrm{G} 1 \mathrm{mt}^{+}$. mt: mating type; $C: W$, coloured: white spore

$\begin{array}{lccccc}0 \mathrm{C}: 8 \mathrm{~W} & 1 \mathrm{C}: 7 \mathrm{~W} & 2 \mathrm{C}: 6 \mathrm{~W} & 3 \mathrm{C}: 5 \mathrm{~W} & 2 \mathrm{C}: 6 \mathrm{~W}^{*} & \mathrm{~N} \\ 1841 & 131 & 22 & 1 & 5 & 2000\end{array}$

* Odd segregations for spore colour and spore shape: 1 oval coloured, 1 round coloured, 3 oval white, 3 round white.

correction of $\mathrm{F} 6$ and $\mathrm{A} 1$, without correction of the middle site mutant $\mathrm{G} 1$. Class I ( 81 asci) is compatible with a $5+3 \mathrm{~m}$ segregation of $\mathrm{G} 1$ and a $4+4 \mathrm{~m}$ segregation for F6 or A1 or both. Again this may reflect an independent correction of $\mathrm{F} 6$ and $\mathrm{A} 1$ in some hybrid DNA configurations, but could also arise from situations where hybrid DNA spans the G1 site and only one or none of the 2 sites F6 and A1. Class II ( 3 asci) could arise from complex events involving the 3 markers in two or more chromatids. The results of the second step of the analysis of the class III asci are given in table 4. Three types of ascus were observed: 25 asci corresponded to the postulated events. The two other asci resulted from complex events: they can be explained as resulting from the postulated events accompanied by a simultaneous conversion involving the sister chromatid. The frequency of the postulated events, calculated from the data of tables 2,3 and 4 is $0 \cdot 016$.

\section{TABLE 3}

Analysis of $1 C$ : 7W asci: crosses with b2-F6A1. One white spore strain from each pair was tested for each ascus. The spore pair No.1 is the mixed one (wild-type/mutant)

\begin{tabular}{|c|c|c|c|}
\hline \multirow[b]{2}{*}{ Spore pair No. } & \multicolumn{3}{|c|}{ Ascus class } \\
\hline & I & II & III \\
\hline 1 & + & + & + \\
\hline 2 & + & - & + \\
\hline 3 & - & - & + \\
\hline 4 & - & - & - \\
\hline $\begin{array}{l}\text { Total number } \\
\text { of asci }\end{array}$ & 81 & 3 & 27 \\
\hline
\end{tabular}

TABLE 4

Results of complete genotype analysis of class III 1C:7W asci (table 3) Spore pair No.

$\begin{array}{ccccc}1 & & & & \text { Number } \\ \text { of asci }\end{array}$




\section{Discussion}

The existence of $1 \mathrm{C}: 7 \mathrm{~W}$ with a $6+2 \mathrm{~m}$ segregation at ouside sites $\mathrm{F} 6$ and $A 1$ and a $3+5 \mathrm{~m}$ segregation at $\mathrm{G} 1$ indicates that two independent corrections can occur along the same HDNA segment. The question now arises whether the two corrections triggered at the outside sites always leave the middle site uncorrected. It is possible to calculate the expected frequency of $1 \mathrm{C}: 7 \mathrm{~W}$ asci with a $6: 2 / 5: 3 / 6: 2$ segregation in the situation of systematic non-overlapping of the middle site by the repair tracts. We have information about the HDNA distribution pattern along the $b 2$ locus (Paquette and Rossignol, 1978; Paquette, 1979; Rossignol and Paquette, 1979; Rossignol and Haedens, 1980). The data are consistent with HDNA always starting on the left side of $b 2$ (high conversion end) and extending to the right. HDNA formation is mostly asymmetrical in the left part of the locus and mostly symmetrical in the right part. These two modalities of HDNA formation show physical association. Lastly, the conversion parameters of the mutants used (Paquette and Rossignol, 1978; Paquette, 1979) have been calculated from the conversion pattern of these mutants (table 5).

TABLE 5

Values of the conversion parameters of the mutants used

$\begin{array}{llccc}\text { Mutant } & \gamma & \alpha & p & v \\ b 2 . \mathrm{F} 6 & 0.391^{\mathrm{a}} & 0.924^{\mathrm{a}} & 1 \cdot 000 & 0.738 \\ b 2 . \mathrm{G} 1 & 0.234 & 0.673 & 0.268 & 0.331 \\ b 2 . \mathrm{A} 1 & 0.166^{\mathrm{b}} & 0.278^{\mathrm{b}} & 1.000 & 0.734\end{array}$

Sources: Paquette and Rossignol, 1978; Paquette, 1979.

$\gamma$ : Frequency of HDNA formation per meiosis at the mutant site.

$\alpha$ : Probability that HDNA, undergoes asymmetrical distribution.

$p$ : Frequency of correction per mismatch.

$v$ : Probability that the correction leads to a wild-type homoduplex.

a: Mean of the values obtained for the C type mutants 1F1, F1, F2 and $8 \mathrm{E}$ located within group $F$; b: mean value for $\mathrm{A} 4$ located within group $A$.

In order to calculate from these parameters the frequency of the different types of HDNA distribution along the $b 2$ locus when the 3 sites are involved in HDNA, the three following assumptions were made:

(1) When HDNA covers A1 which is at the low conversion end of the $b 2$ locus, it also covers the 2 other sites. In other words, there is a complete polarisation of HDNA formation. Thus, the frequency of HDNA covering the 3 sites is the same as the frequency over the A1 site (table 5).

(2) When HDNA shows a symmetrical distribution at one site, it also shows symmetrical distribution at all other sites to the right. In other words, transition from symmetrical to asymmetrical distribution is not possible. This assumption is based on the data presented by Rossignol and Haedens (1980) for the $b 2$ locus.

(3) When HDNA distribution is asymmetrical it involves either parental chromatid with equal probability.

The expected frequencies of the various distributions of HDNA when HDNA involves the 3 sites, are given in fig. 2 . In the same figure, the 


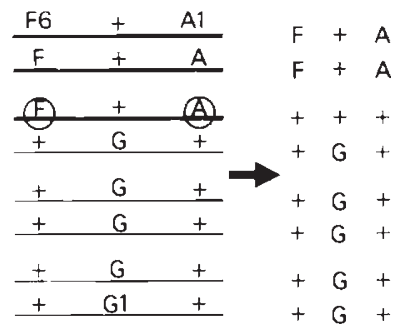

$1 \gamma_{\mathrm{A}} \alpha_{\mathrm{A}}: 2=0.023$

$20.023 p_{F} v_{F}\left(1-p_{G}\right) p_{A} v_{A}=0.0091$

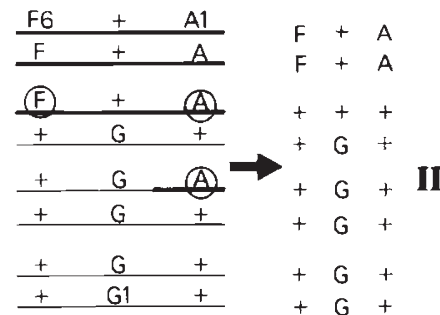

$1 \gamma_{A}\left(\alpha_{G^{-}}-\alpha_{A}\right): 2=0.033$

$20.033 p_{F} v_{F}\left(1-p_{G}\right) p_{A}^{2} v_{A}^{2}=0.0096$

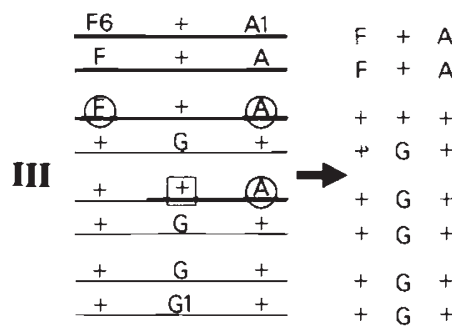

$\gamma_{\mathrm{A}}\left(\alpha_{\mathrm{F}}-\alpha_{\mathrm{G}}\right): 2=0.021$

$0.021 p_{F} v_{F} 2\left(1-p_{G}\right) p_{G}\left(1-v_{G}\right) p_{A}^{2} v_{A}^{2}=0.0022$

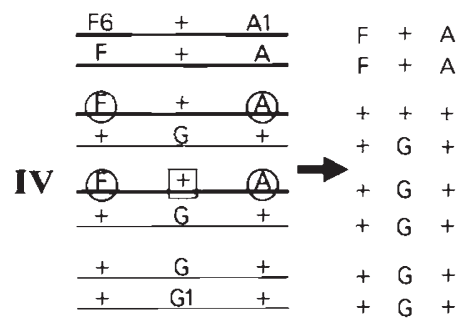

$\check{\varkappa}_{\mathrm{A}}\left(1-\alpha_{\mathrm{F}}\right)=0.013$

$0.013 p_{F}^{2} v_{F}^{2} 2\left(1-p_{G}\right) p_{G}\left(1-v_{G}\right) p_{A}^{2} v_{A}^{2}=0.0010$

FIG. 2.- Modalities of HDNA distribution when all three sites are involved in the HDNA segment on the F6 + A1 chromatid. In I, II and III the reciprocal distribution (when all three sites are involved in the HDNA segment on the $+\mathrm{G} 1+$ chromatid) is not represented because they cannot lead to a $6+2 \mathrm{~m} / 3+5 \mathrm{~m} / 6+2 \mathrm{~m}$ segregation. The frequencies of the corresponding HDNA distributions are given in 1. In each HDNA segment, the corrected strand is indicated by a circle at $F 6$ and $A 1$ sites and by a square at $\mathrm{G} 1$ site. The frequencies of $1 \mathrm{C}: 7 \mathrm{~W}$ asci presenting a $6+2 \mathrm{~m} / 3+5 \mathrm{~m} / 6+2 \mathrm{~m}$ segregation are given in 2 for each HDNA distribution. F, G and $A$ indexes indicate the mutant site to which the parameters correspond. For definitions and sources of $\gamma, \alpha, p, v$ see table 5. The total frequency of $1 \mathrm{C}: 7 \mathrm{~W}$ asci presenting a $6+2 \mathrm{~m} / 3+5 \mathrm{~m} / 6+2 \mathrm{~m}$ segregation is 0.022 (sum of $\mathrm{I}_{2}+\mathrm{II}_{2}+$ $\mathrm{III}_{2}+\mathrm{IV}_{2}$ ).

expected frequencies of $1 \mathrm{C}: 7 \mathrm{~W}$ asci corresponding to a $6+2 \mathrm{~m} / 3+5 \mathrm{~m} / 6+$ $2 \mathrm{~m}$ segregation obtained from each HDNA distribution are also given. On this basis, the expected frequency of $6+2 \mathrm{~m} / 3+5 \mathrm{~m} / 6+2 \mathrm{~m}$ segregation is $0 \cdot 022$ (fig. 2) which is close to that observed $(0 \cdot 016)$. We thus conclude that the data are compatible with a model in which the corrections triggered at F6 and A1 mismatches never or rarely span the middle G1 mismatch.

This study shows that, in the $b 2$ locus, the size of the repair tract is often and perhaps always significantly shorter than the size of the HDNA segment since at least two non overlapping correction tracts can readily occur within the HDNA length. Thus our results are in agreement with the idea that the distances between $F$ or $A$ and G1 are larger than the maximal sizes of the repair tract. Previous studies suggested that the size of the repair tract could show large variations (Rossignol and Haedens, 1978 and Paquette, 1979). More particularly the study of two-point crosses within the $F$ group of intragenic suppression showed the existence of 4 wild-type: 4 mutant 
recombinant asci. These asci were shown to result from double site conversion to wild-type (Paquette, 1979). They can only be explained by independent corrections at the two sites. Although rare, these asci were observed for very small intervals; in the largest intervals within group $F$ their frequency was still smaller than expected if independent corrections always occur. Consequently the size of the correction can be smaller than the small intervals in group $F$ but can also be larger than the largest interval in this group. It is only for crosses between alleles located in distinct groups of intragenic suppression that the size of the correction tract is systematically smaller than the interallelic distances considered, as shown by the present work. On.Fincham and Holliday's (1970) interpretation of map expansion, one expects map expansion for the relatively short distances studied by Paquette, and this was indeed observed. When the interallelic distance systematically exceeds the length of the repair tract, as in the situation described in the present work, map contraction should be observed. The systematic study of two-point crosses for mutants located in various sites in locus $b 2$ should permit this prediction to be verified.

Acknowledgments. - The authors wish to thank Mrs S. Le Bilcot and Mrs M. Dahuron for their excellent technical assistance. We thank Dr P. J. Hastings, Dr G. Leblon and Dr P. Thuriaux for critical reading of the manuscript. This investigation was supported by grants from the Centre National de la Recherche Scientifique (L.A. 86).

\section{REFERENCES}

FINCHAM, J. R. S., AND HOLLIDAY, R. 1970. An explanation of fine structure map expansion in terms of excision repair. Molec. Gen. Gen., 109, 309-322.

FOGEL, S., MORTIMER, R. K., LUSNAK, K., ANDTAVARES, F. 1979. Meiotic gene conversion: A signal of the base recombination event in yeast. Cold Spring Harbor Symposia, XLIII, 1325-1341.

LEBLON, G. 1972a. Mechanism of gene conversion in Ascobolus immersus. I. Existence of a correlation between the origin of mutants induced by different mutagens and their conversion spectrum. Mol. Gen. Genet., 115, 36-48.

LEBLON, G. 1972 b. Mechanism of gene conversion in Ascobolus immersus. II. The Relationships between the genetic alterations in $b 1$ or $b 2$ mutants and their conversion spectrum. Molec. Gen. Genet., 116, 322-335.

LEBLON, G., AND PAQUETTE, N. 1978. Intragenic suppression at the $b 2$ locus in Ascobolus immersus. I. Identification of three distinct groups of suppression. Genetics, 90, 475-488.

LEBLON, G., AND ROSSIGNOL, J.-L. 1973. Mechanism of gene conversion in Ascobolus immersus. III. The interaction of heteroalleles in the conversion process. Mol. Gen. Genet., 122, 165-182.

LISSOUBA, P., MOUSSEAU, J., RIZET, G., AND ROSSIGNOL, J.-L. 1962. Fine structure of genes in Ascobolus immersus. Adv. Genet., 11, 343-380.

NiCOLAS, A. 1978. Carte génétique et fréquences de conversion dans le génome d'Ascobolus immersus. Thése Doctorat 3 ème cycle $108 \mathrm{pp}$. Université Paris-Sud, Centre d'Orsay.

PAQueTte, N. 1979. Polarité multiple de la recombinaison génétique dans le locus $b 2$ d'Ascobolus immersus. Thèse Doctorat d'Etat, $321 \mathrm{pp}$. Université Paris-Sud, Centre d'Orsay.

PAQUETTE, N,, AND ROSSIGNOL, J.-L. 1978. Gene conversion spectrum of 15 mutants giving postmeiotic segregation in the locus 62 in Ascobolus immersus. Molec. Gen. Genet., 163, 313-326.

RIZET, G., ENGELMAN, N., LEFORT, C., LISSOUBA, P., AND MOUSSEAU, J. 1960. Sur un Ascomycète intéressant pour l'étude de certains aspects du problème de la structure du gène. C. R. Acad. Sci. (Paris), 270, 2050-2052.

RIZET, G., ROSSIGNOL, J.-L., AND LEFORT, C. 1969. Sur la variété et la spécificité des spectres d'anomalies de ségrégations chez Ascobolus immersus. C. R. Acad. Sci. (Paris), $269,1427-1430$. 
ROSSIGNOL, J.-L., AND HAEDENS, V. 1978. The interaction during recombination between closely linked allelic frameshift mutant sites in Ascobolus immersus. Heredity, 40, 405-425. ROSSIGNOL, J.-L., AND HAEDENS, V. 1980. Relationship between asymmetrical and symmetrical hybrid DNA formation during meiotic recombination. Cur. Genet., 1, 185-191.

ROSSIGNOL, J.-L., AND PAQUETTE, N. 1979. Disparity of gene conversion in frameshift mutants located in locus $b 2$ of Ascobolus immersus. Proc. Nat. Acad. Sci. 76, 2871-2875.

ROSSIGNOL, J.-L., PAQUETTE, N., AND NICOLAS, A. 1979. Aberrant $4: 4$ asci, disparity in the direction of conversion and frequencies of conversion in Ascobolus immersus. Cold Spring Harbor Symposium XLIII, 1343-1352.

SPATZ, H., CH., AND TRAUTNER, T. A. 1970. One way to do experiments on gene conversion? Transfection with heteroduplex SPP1/DNA. Mol. Gen. Genet., 109, 84-106.

WAGNER, R., AND MESELSON, M. 1976. Repair tracts in mismatched DNA heteroduplexes. Proc. Nat. Acad. Sci., 73, 4135-4139.

WHITEHOUSE, H. L. K. AND HASTINGS, P. J. 1965. The analysis of genetic recombination on the polaron hybrid DNA model. Gen. Res., 6, 27-92.

WILDENBERG, J., AND MESELSON, M. 1975. Mismatch repair in heteroduplex DNA. Proc. Nat. Acad. Sci., 72, 2202-2206.

YU-SUN, C. C. 1964. Biochemical and morphological mutants of Ascobolus immersus. Genetics, 50, 987-998. 